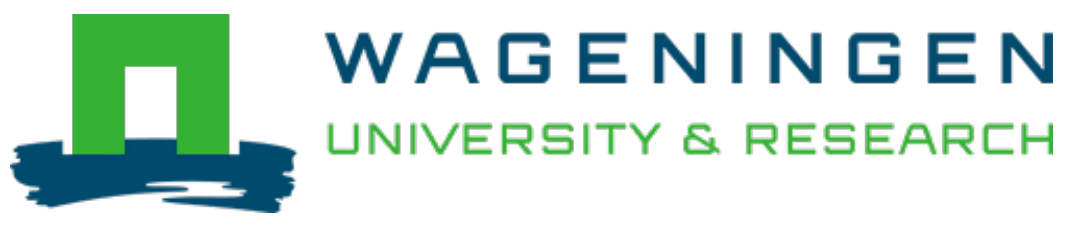

\author{
Reducing cassava toxicity by heap-fermentation in Uganda. \\ International Journal of Food Sciences and Nutrition \\ Essers, A.J.A.; Ebong, C.; Grift, R.M.; Nout, M.J.R.; Otim-Nape, W. et al \\ https://doi.org/10.3109/09637489509012540
}

This publication is made publicly available in the institutional repository of Wageningen University and Research, under the terms of article $25 \mathrm{fa}$ of the Dutch Copyright Act, also known as the Amendment Taverne. This has been done with explicit consent by the author.

Article $25 \mathrm{fa}$ states that the author of a short scientific work funded either wholly or partially by Dutch public funds is entitled to make that work publicly available for no consideration following a reasonable period of time after the work was first published, provided that clear reference is made to the source of the first publication of the work.

This publication is distributed under The Association of Universities in the Netherlands (VSNU) 'Article $25 \mathrm{fa}$

implementation' project. In this project research outputs of researchers employed by Dutch Universities that comply with the legal requirements of Article $25 \mathrm{fa}$ of the Dutch Copyright Act are distributed online and free of cost or other barriers in institutional repositories. Research outputs are distributed six months after their first online publication in the original published version and with proper attribution to the source of the original publication.

You are permitted to download and use the publication for personal purposes. All rights remain with the author(s) and / or copyright owner(s) of this work. Any use of the publication or parts of it other than authorised under article $25 \mathrm{fa}$ of the Dutch Copyright act is prohibited. Wageningen University \& Research and the author(s) of this publication shall not be held responsible or liable for any damages resulting from your (re)use of this publication.

For questions regarding the public availability of this publication please contact openscience.library@wur.nl 


\title{
Reducing cassava toxicity by heap-fermentation in Uganda
}

\author{
A. J. A. Essers, ${ }^{1}$ C. Ebong, ${ }^{2}$ R. M. van der Grift, ${ }^{2}$ M. J. R. Nout, ${ }^{1}$ W. Otim-Nape ${ }^{2}$ and \\ H. Rosling ${ }^{3}$
}

'Deparment of Food Science, Wageningen Agricultural University, Bomenweg 2, 6703HD Wageningen, The Netherlamds; ${ }^{2}$ Namulonge Research Station, P.O. Box 7084, Kampala, Uganda; ${ }^{3}$ Intemational Child Health Unit, University Hospital, S-75185 Uppsala, Sweden

\begin{abstract}
Processing of cassava roots by the Alur tribe in Uganda includes a stage of solid substrate fermentation in heaps. Changes in cyanogen levels during the process, microflora involved, and protein levels, amino acid patterns and mycotoxin contamination of the final products were studied. Processing was monitored at six rural households and repeated at laboratory site, comparing it to sun-drying. Flour samples from rural households were analysed for residual cyanogens, mutagenicity, cytotoxicity and aflatoxins. Mean $( \pm S D)$ total cyanogen levels in flours collected at rural households were $20.3( \pm 16.8) \mathrm{mg} \mathrm{CN}$ equivalents $\mathrm{kg}^{-1}$ dry weight in $1990(n$ $=23)$ and $65.7( \pm 56.7)$ in $1992(n=21)$. Mean $( \pm S D)$ levels of cyanohydrins plus HCN were $9.1( \pm 8.7)$ in the 1992 flours. Total cyanogen levels in the village monitored batches were reduced considerably by heap-fermentation from 436.3 $( \pm 140.7)$ to $20.4( \pm 14.0) \mathrm{mg} \mathrm{CN}$ equivalents $\mathrm{kg}^{-1}$ dry weight cassava. Residual cyanogen levels were positively correlated with particle size of the resulting crumbs. Heap-fermentation was significantly more effective in reducing cyanogen levels than sun-drying alone, but did not always result in innocuous levels of cyanogens. Dominant mycelial growth was from the fungi Neurospora sitophila, Geotrichum candidum and Rhizopus oryzae. No mutagenicity, cytotoxicity nor aflatoxins could be detected in the flours. Protein quantity and quality were not significantly reduced. Cassava gel viscosity pattem was modified to the consumers' preference by this method. As the removal of cyanogens was more efficient and we found no new obvious health risk, heap-fermentation can be regarded as an improvement compared to sun-drying alone in areas where cassava varieties with higher cyanogen levels prevail, but we recommend optimisation of the process for ensuring still safer products.
\end{abstract}

\section{Introduction}

Due to several agronomic advantages, the starchy root crop cassava has become the second most important staple food in Uganda, and it presently supplies one quarter of the dietary energy in the country (Romanoff \& Lynam, 1992). An aspect of cassava, especially of bitter varieties, that merits special attention is its cyanogenic potential. The cyanogenic glucosides, mainly linamarin, in the plant cells can be cleaved by the enzyme linamarase, located in the cell walls (Mkpong et al., 1990). The cyanohydrins formed are increasingly unstable at a $\mathrm{pH}$ higher than 5 , yielding the volatile hydrogen cyanide (HCN) (Cooke, 1978). Dietary cyanide exposure from insufficiently processed cassava is a factor in some public health problems (Rosling, 1993), but the dynamics of cyanogen removal during processing and the mechanisms 
of cyanide exposure from insufficiently processed cassava are not yet fully understood.

People of the Alur tribe, living mainly in north-west Uganda, traditionally apply a process involving solid substrate fermentation in covered heaps, heap-fermentation, on their predominantly bitter - cassava roots. The aim is to reduce toxicity and improve palatability of the stiff porridge that they prepare from the resulting flour. For outsiders the process seems in uncontrolled way' of rotting, leading to 'a most unappetising looking article' (Anderson, 1944). The method was earlier reported from Kenya by Anderson (1944), from Tanzania by Childs (1961), from Uganda by Goode (1974), and from Mozambique by Essers et al. (1992), but it was never studied in detail. The Uganda Ministry of Agriculture recently noted that the use of bitter cassava varieties and the heapfermentation practice seem 10 be spreading from the western part of Uganda to find acceptance in other parts of the country. The Ministry's concern about these developments led to this study.

This paper reports on the processing of cassava roots by heap-fermentation in Uganda. It presents the dynamics of cyanogen removal, and the residual cyanogen levels, associated microllora, absence of mycotoxins, protein quantity and quality of the flours obtained, viscosity of a gel prepared from them, and discusses product safety.

\section{Materials and methods}

\section{Study area}

Monitoring of the heap-fermentation process, sample collection and interviewing took place in Kiryandongo village, a trading locality in Masindi district, located along a tar road, $200 \mathrm{~km}$ north-west of Kampala. In the last decades, much migration has taken place in this area, and in the village approximately 50 tribes are represented, according to the District Administration. The village was selected for its situation as one of the rural areas nearest to the capital where cassava is the main staple crop and heap-fermentation is commonly applied by a substantial number of its inhabitants.

\section{Interviews}

After information gathering from several key informants in Kampala, semi-structured inter- views were held in 1990 in 11 of the households where cassava samples were collected. The information from observations and these interviews was validated in focus group interviews (Melville, 1993). This was done with one group of about 10 young and elderly women of the Alur tribe and one group of women of the Banyoro tribe in Kiryandongo village. The interviews focused on the common cassava processing and deviations from it, why and when the process is applied, how people learned about it, reasons for choosing bitter varieties and knowledge of toxic effects from cassava.

\section{Flour sample collection}

Dried fermented cassava crumbs of the bitter variety karangwa, considered ready for conversion to flour and preparation, were collected at consecutive Alur households in Kiryandongo village in April and September 1990 (23 samples) and in October 1992 (21 samples). The number of storage days and the anticipated use were registered. After processing, the products had been stored in this form for 1-9 days. In 1990, samples were extracled 2-10 days after collection, and the extracts were stored frozen between 1 and 4 months until analysis for total cyanogens. In 1992, samples were extracted on the day of collection. The extracts were stored deep-frozen and analysed for cyanogens within 14 days.

\section{Monitored processing}

All processing steps applied to the variety karangwa were closely observed at six individual households in Kiryandongo village in September 1990. Temperature was measured every morning inside and outside the heaps. One or more samples were taken at every stage (six) of the process for determination of microflora, $\mathrm{pH}$, moisture and cyanogen levels. At two households, half (lengthwise) of each fresh root of the initial sample was sliced, sun-dried and pounded into flour, to serve as non-femented controls. Cyanogen extraction and $\mathrm{pH}$ determination were done within $4 \mathrm{~h}$ after collection, in the village.

\section{Experimental processing at laboratory site}

To verify the results from the village based processing, the same processing method was performed and extended in February 1992 by an experienced Alur farmer from Kiryandongo at a 
laboratory site in Kimpala, as follows. Within $3 \mathrm{~h}$ after harvest, 300 roots of cultivar TMS 30572 from Namulonge Research Station were peeled and divided over five batches, using a randomised schedule. Roots of the first batch were split in quarterly segments, to facilitate drying and avoid fermentation during the humid weather, and sun-dried for 6 days on a cane mat. The other four batches were submitted to heapfermentation. On day 6 all remaining roots were pounded batch-wise into flour and cooked into a stiff porridge, ugali. Sampling took place at each stage.

\section{Sample preparation at monitored and experimental processing}

Twelve whole roots were selected at random and split once lengthwise. Half of each root was discarded to reduce sample size without violating cyanogen levels (De Bruijn, 1971). Remaining halves were diced to approximately $1 \mathrm{~cm}^{3}$, hand-mixed and four subsamples of $70.0 \mathrm{~g}$ were each homogenised in a blender (Braun MX2 Melsungen, Germany) with $250 \mathrm{ml}$ extraction medium (e.m.), consisting of $0.1 \mathrm{M}$ orthophosphoric acid, supplemented with $25 \%$ cthanol in the village-made extracts for improved storability (O'Brien et al., 1991). For moist crumbs, two subsamples of approximately $50 \mathrm{~g}$ were each homogenised in $150 \mathrm{ml}$ e.m. For flours, two subsamples of approximately $4 \mathrm{~g}$ were each suspended in $25 \mathrm{ml} \mathrm{c.m}$. and swirled for $10 \mathrm{~min}$. Dry crumbs were pounded into flour and extracted accordingly. From the cooked flours (ugali), two subsamples of approximately $50 \mathrm{~g}$ were each homogenised in $150 \mathrm{ml}$ e.m. Extraction took place by centrifuging the homogenates and suspensions. Samples were extracted within $4 \mathrm{~h}$ after collection.

Village-made extracts of 1990 were stored below $15^{\circ} \mathrm{C}$ for $2-16$ days and subsequently at $-18^{\circ} \mathrm{C}$ until analysis of cyanogens within 4 months. The extracts from the laboratory-site experiments were stored at $-18^{\circ} \mathrm{C}$ and analysed within 2 weeks for cyanohydrins plus $\mathrm{HCN}$, and within 2 months for total cyanogens.

\section{Cyanogen, moisture and $p H$ determination}

Total cyanogens, as well as cyanohydrins and $\mathrm{HCN}$ were assayed according to Essers et al. (1993). Moisture levels were assayed by oven drying of 30 to $40 \mathrm{~g}$ at $105 \pm 5^{\circ} \mathrm{C}$ until constant weight. The $\mathrm{pH}$ was measured $10 \mathrm{~min}$ after homogenising approximately $40 \mathrm{~g}$ cassava dices or crumbs in $150 \mathrm{ml}$ or suspending $10 \mathrm{~g}$ flour in $100 \mathrm{ml}$ cooled, previously boiled distilled water:

\section{Consistency characteristics}

Viscosity at gelatinisation was measured in the village fermented flours and the two sun-dried control flours by means of a Brabender viscoamylograph Duisburg, Germany, applying $30 \mathrm{~g}$ flour to $450 \mathrm{ml}$ water, a rotation speed of $75 \mathrm{rev}$ $\min ^{-1}$ and a $350 \mathrm{~cm} \mathrm{~g}^{-1}$ measuring cartridge. Temperature was increased from 50 to $95^{\circ} \mathrm{C}$ at a range of $1.5^{\circ} \mathrm{C} \mathrm{min}^{-1}$, thereafter kept at $95^{\circ} \mathrm{C}$ for $30 \mathrm{~min}$ and then lowered to $50^{\circ} \mathrm{C}$ also at $1.5^{\circ} \mathrm{C} \mathrm{min}-1$.

\section{Crude protein and amino acid determination}

Crude protein was calculated by multiplying the nitrogen level, assayed with a routine Kjeldahl method, by 6.25. Amino acids were analysed chromatographically according to Stein \& Moore (1963) with a Merck Biotronic LC-5001 analyser (Darmstadt, Germany). The amino acids were released by hydrolysis by boiling for $22 \mathrm{~h}$ with $6 \mathrm{M} \mathrm{HCl}$. The determination of cysteine and methionine was preceded by oxidation with performic acid, which was later bound to bisulfite. Chemical score per essential amino acid was calculated as $\mathrm{mg}$ amino acid per $\mathrm{g}$ of crude protein, divided by its value in the reference protein, times 100 (FAO/NHO, 1972).

\section{Mutagenicity and cytotoxicity}

The presence of mycotoxins was estimated by assaying mutagenicity and cytotoxicity by the Ames test (Maron \& Ames, 1983) on extracts of 25 flours and one sample of dried scraped-off moulds, using the tester strains Salmonella typhimurium TA100 and TA98, with and without the addition of 59 liver homogenate. Samples of $100 \mathrm{~g}$ were extracted according to Filtenborg et al. (1983). Calibration curves of mutagenicity were made from commercial aflatoxin $B_{1}$ and sterigmatocystine in serial dilutions up to 1 and $10 \mu g$, respectively, per plate. The recovery of these compounds supplemented to flours was higher than $80 \%$. A positive dose-response relation indicates an induced mutagenicity. A negative doseresponse relation indicates cytotoxicity. The detection limit for mutagenicity was calculated at $2.5 \mathrm{~kg}$ of aflatoxin $\mathrm{B}_{1}$ per $\mathrm{kg}$ of flour. 


\section{Aflatoxin determination}

Aflatoxins were assayed chemically by HPTLC (Soares \& Rodriguez-Amaya, 1989) in 10 flour samples after extraction with methanol. The detection limit for aflatoxin was $2.0 \mu \mathrm{g} \mathrm{kg}^{-1}$.

\section{Microbiological analysis}

Cassava flour samples were pre-soaked $(10 \mathrm{~g}$ sample in $90 \mathrm{ml}$ peptone physiological salt solution) for $15 \mathrm{~min}$ and then homogenised for 1 min in a Colworth Stomacher blender (London, UK). Serial dilutions were made with peptone physiological salt solution containing $1 \mathrm{~g}$ bacteriological peptone and $8.5 \mathrm{~g} \mathrm{NaCl}$ per litre. Total aerobic mesophiles were counted in pour plates of plate count agar (Oxoid CM 325) incubated at $30^{\circ} \mathrm{C}$ for 3 days. The same medium was used for counting bacterial endospores in a tenfold dilution of the sample which was kept at $80^{\circ} \mathrm{C}$ for $10 \mathrm{~min}$. Lactobacillus spp were counled in pour plates of Rogosa agar (LSB agar, BBL 11327, Cockeysville, MD, USA) containing $0.2 \%$ Natamycin (Delvocid, Gist Brocades, Delft, The Netherlands) with overlay and incubated at $30^{\circ} \mathrm{C}$ for $3-5$ days. Micrococcaceae were counted in pour plates of Mannitol salt agar (Oxoid CM 85, Basingstoke, UK) incubated at $30^{\circ} \mathrm{C}$ for 2 days. Pseudomonas were counted in surface-inoculated plates of Pseudomonas agar $F$ (Difco 0448-01, Surrey, UK) incubated at $30^{\circ} \mathrm{C}$ for 4 days. Enterobacteriaceae were counted in overlaid pour plates of violet red bile glucose agar (Merck 10275) incubated at $30^{\circ} \mathrm{C}$ for $24 \mathrm{~h}$. Coliform bacteria were counted in overlaid pour plates of violet red bile agar (Oxoid CM 107) incubated at $30^{\circ} \mathrm{C}$ for $24 \mathrm{~h}$. Escherichia coli were enumerated using a three lube MPN method with nonselective pre-enrichment in buffered peptine water (Oxoid $\mathrm{CM} 509$ ) at $37^{\circ} \mathrm{C}$ for $24 \mathrm{~h}$, followed by selective enrichment in brilliant green bile $(2 \%)$ broth (Oxoid CM 31 ) at $44^{\circ} \mathrm{C}$ for $48 \mathrm{~h}$. Positive tubes were confirmed using violet red bile agar, incubated at $37^{\circ} \mathrm{C}$ for $24 \mathrm{~h}$. Bacillus cereus were enumerated on surfaceinoculated plates of Mannitol egg yolk Polymyxin agar (Merck 5267) with addition of Polymyxin B sulphate (Pfizer 90 A02, New York, USA). Clostridium perfringens were estimated using a three tube MPN method with selective enrichment in rapid perfringens medium (thioglycollate medium Oxoid CM 173 with additions of $60 \mathrm{~g}$ gelatin, $5 \mathrm{~g}$ peptone, $5 \mathrm{~g}$ glucose, $\quad 5 \mathrm{~g} \mathrm{~K}_{2} \mathrm{HPO}_{4}, \quad 3 \mathrm{~g}$ yeast extract, $1.5 \mathrm{~g} \mathrm{NaCl}_{0} 0.5 \mathrm{~g} \mathrm{FeSO}_{4}, 70 \mathrm{~g}$ non-fat milk powder, $0.5 \mathrm{~g}$ litmus, 0.075 neomycin sulphate and $0.0125 \mathrm{~g}$ polymyxin B-sulphate, per litre) incubated at $46^{\circ} \mathrm{C}$ for $24 \mathrm{~h}$, with confirmation on cycloserine agar (perfringens agar base, Oxoid CM 587 with D-cycloserine, Serra 17685), incubated anaerobically at $37^{\circ} \mathrm{C}$ for $48 \mathrm{~h}$. Staphylococcus aureus were counted in pour plates of Baird Parker agar (Gibco 152-00320 M, Life Technologies Ltd, Paisley, Scotland, with RPF supplement Oxoid SR 122), incubated at $37^{\circ} \mathrm{C}$ for $24-48 \mathrm{~h}$. Salmonella were detected by preincubating $25 \mathrm{~g}$ sample in buffered peptone water at $37^{\circ} \mathrm{C}$ for $18 \mathrm{~h}$, followed by selective enrichment in Muller Kaufmann broth (Oxoid CM 343), or Rapaport Vasiliadis broth MSRV (Difco) at $42.5^{\circ} \mathrm{C}$ for $48 \mathrm{~h}$ and detection on brilliant green agar incubated at $37^{\circ} \mathrm{C}$ for $24 \mathrm{~h}$. Yeasts and filamentous fungi were enumerated and isolated on oxytetracycline glucose yeast extract agar (Oxoid CM 549), dichloran-glycerol medium (Oxoid CM 729) and rose bengal chloramphenicol oxytetracylcline agar (Oxoid CM 549, with $150 \mathrm{ppm}$ rose Bengal). Filamentous fungi were identified on the basis of their macro- and microscopic morphology according to Samson \& van Reenen-Hoekstra (1988).

\section{Statistical analysis}

Testing for relations between sample variables in the 1992 randomly collected flours was by F-test, and testing differences between batches was by two-tailed Student's $t$ test (Snedecor \& Cochran, 1980, pages 221 and 93, respectively). Logarithmic transformation of the data was applied where necessary to stabilise the variance. Standard deviations (SD) given are with $\mathrm{n}-\mathrm{I}$ degrees of freedom.

\section{Results}

Application of the heap-fermentation process All 21 Alur interviewees grew both bitter (makesh) and non-bitter (pekesh) cassava varieties. The bitter variety karangwa (also called tongolo) was presently grown most, because of its high yields, early maturation, long storability in the soil, and its low susceptibility to theft and herbivore voracity. Bitter cassava roots always undergo heap-fermentation (kwogu ungura), to reduce toxicity, bitterness and rubberiness before consumption in the form of a stiff 


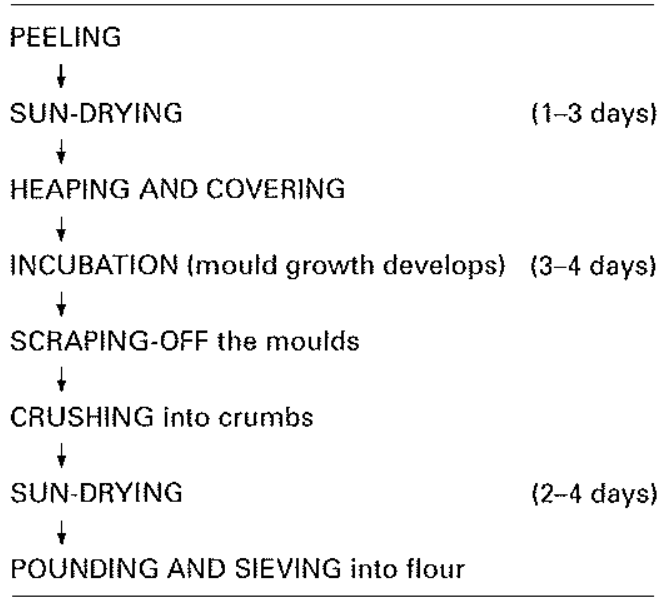

Figure 1. Steps and stages in the heap-fermentation of cassava roots.

porridge (ugali, posho or mogo) made from the resulting flour, and as a preparative step in the processing into waragi, a strong distilled alcoholic beverage. Non-bitter cassava roots may be boiled and eaten as a snack, or sun-dried for flour production and subsequent preparation of a ugali meal, but they are often also heapfermented to obtain the preferred palatability. Ugali from cassava flour is more nubbery (dwadwa) in texture than that from cereals, which is not appreciated. This applies especially to ugali of flour from non-fermented roots. Kneading of ugali from sun-dried flour is considered a heavier task than from heapfermented cassava. Without proper fermentation, bitter cassava is said to remain bitter and induce acute toxic effects like headaches, dizziness, vomiting, diarthoea, palpitations, muscleweakness, and even to 'kill people and animals'. The respondents were convinced of this association, and examples of deaths by accidental cassava poisoning were known by all Alurs interviewed. Waragi from bitter cassava is said to be stronger than from non-bitter cassava, and thus preferred: 'It strikes harder'.

The interviewed Alurs considered the processing of cassava by heap-fermentation as part of their tradition which was taught to them by their parents. The process follows in principle a strict schedule (Figure 1) and requires skill for adaptation to weather conditions. Greenish moulds were considered as a sign of spoilage by the processors, caused by an insufficient first drying step. Initially, white moulds appear, but near the end of the heap phase, the roots should be covered with moulds with a black or - less preferred - orange appearance, or both. The crucial criterion for ending the heap phase was not the time spent, but the softness of the roots. It was observed that the particle size after crushing depended upon the softness of the fermented roots, the weather conditions and the anticipated use of the flour. If used for sale, larger pieces were preferred, as less is needed to a fill a tin, the marketable volume. The interviews revealed that acute toxic effects have been experienced when people were in a hurry because of food shortage or high market demand. Drying and incubation stages were shortened or steps altered. One short-cut method, considered risky, starts with crushing the peeled fresh roots to small particles, followed by covered incubation for two days and subsequent sun-drying. Acute toxic effects have also occurred when the sun-drying steps were hampered by rainy and humid weather. Toxicity of young roots is believed to be higher than of older roots.

Several people from the Banyoro tribe in Kiryandongo village also cultivated the variety karangwa for the market and for brewing, as its yields are high. They also processed it by heapfermentation, which they had learned from the Alur. Some of them, however, recently stopped cultivating bitter cassava varieties because of the tiresome and time consuming heap-fermentation, their dislike of the smell and dark colour of the resulting ugali, and the recent (1990) lower prices for fermented flour induced by the increased production.

Interviewed students of Makerere University originating from other parts of the country (West-Nile, Hoima, Teso) invariably described a heap-fermentation procedure identical to the one used in Kiryandongo, with the only exceptions that in some areas crushing is omitted and in some areas the method is combined with water soaking.

\section{Cyanogen levels}

Monitoring the processing of cassava by heapfermentation in six rural households showed similar patterns of cyanogen levels over time and the same relation to moisture level and $\mathrm{pH}$, though the levels and the time spans differed between batches. Figure 2 shows the pattern of one of the households as an example. Mean 


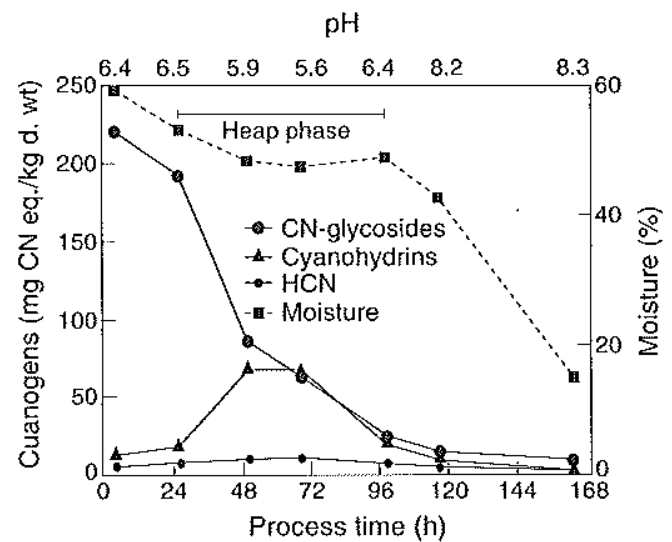

Figure 2. Cyanogen levels in a batch of cassava roots (variety karangwa) during donestic processing by heaplementation.

$( \pm \mathrm{SD})$ initial total cyanogen level was 436 $( \pm 141) \mathrm{mg} \mathrm{CN}$ equivalents $\mathrm{kg}^{-1}$ dry weight and residual level in the flours was $20.4( \pm 14.0) \mathrm{mg}$ $\mathrm{CN}$ eq. $\mathrm{kg}^{-1}$ dry weight or $4.5 \%( \pm 2.2)$ of the initial level. Mean residual level of cyanohydrins plus HCN in the flours was $2.8( \pm 2.4) \mathrm{mg}$ $\mathrm{CN}$ eq. $\mathrm{kg}^{-1}$ dry weight. Duration of the processing varied from 5-9 days. Mean $( \pm S D)$ moisture levels were reduced from $64 \%( \pm 3)$ to $53 \%$ $( \pm 5)$ during the first drying step, and to $13 \%$ $( \pm 2)$ in the resulting flours. Mean $( \pm S D)$ initial $\mathrm{pH}$ levels were $6.3( \pm 0.1)$, followed at first by a decrease to $5.5( \pm 0.4)$ during the fermentation stage, and gradually increasing to $7.7( \pm 0.6)$ in the flours. Ambient temperature near the heaps fluctuated between 23 and $29^{\circ} \mathrm{C}$. Temperature of the incubated roots on the last incubation day was $2-12^{\circ} \mathrm{C}$ higher than this, with a recorded maximum of $35^{\circ} \mathrm{C}$. Crushing of the moist fermented roots resulted in crumbs of up to $2 \frac{1}{2} \mathrm{~cm}$. Separate sampling and analysis of smaller $(<1 / 2 \mathrm{~cm} \phi)$ and larger $(>1 \mathrm{~cm} \phi)$ crumbs per batch at various moments during drying (Table 1) showed that levels of cyanogenic glucosides, as well as cyanohydrins plus free cyanide, in small crumbs were significantly lower than in big crumbs $(P=0.0016$ and $P=$ 0.015 , respectively, after $\log$ transformation). The differences in cyanogen levels between big and small crumbs could not be attributed to differences in moisture levels. We observed in the village monitored processing that the larger crumbs originated mostly from the less affected inner parts of the thicker roots.

Figure 3 shows the mean $( \pm S D)$ cyanogen levels of the four batches during processing by heap-fermentation at laboratory site and Figure 4 shows the mean $( \pm \mathrm{SD})$ cyanogen levels of four subsamples of the batch of sun-drying roots as control. Lab-site experimental processing showed significantly lower levels $(P<0.001, P$ $<0.02$ after $\log$ transformation) of residual glucosides in the heap-fermented batches $(3.4 \pm$ 1.3) than in the sun-dried cassava $(40.3 \pm 2.7)$. Also, cyanohydrin levels were significantly lower $(P<0.025)$ in fermented batches $(12.3 \pm$ 2.8 ) than in the sun-dried cassava $(37.8 \pm 1.2)$.

All 10 assayed cooked samples (ugali) had similar levels of total cyanogens on dry weight basis to the flours from which they were derived.

Table 1. Levels of glucositlic and non-glucosidic cyanogens (mg CN eg. $\mathrm{kg}^{-3}$ dry weight) and moisture (\%) of small $(<1 / 2 \mathrm{~cm}$ ) and farge $(>2 \mathrm{~cm}$ (1) crumbs of crushed heap-fermented cassava from six heaps at different moments during the drying stage

\begin{tabular}{|c|c|c|c|c|c|c|}
\hline \multirow[b]{2}{*}{ Sample no. } & \multicolumn{3}{|c|}{ Big crumbs } & \multicolumn{3}{|c|}{ Small crambs } \\
\hline & CN-glucosidic & $n g C N$ & Moisture & $C N$-ghterosidic & $n g C N$ & Moisture \\
\hline 1 & 125.3 & 9.5 & 49 & 3.0 & 7.0 & 37 \\
\hline 2 & 36.0 & 3.9 & 46 & 3.3 & 8.4 & 44 \\
\hline 3 & 65.1 & 26.9 & 41 & 27.5 & 7.0 & 45 \\
\hline 4 & 56.2 & 17.0 & 39 & 9.7 & 3.6 & 20 \\
\hline 5 & 150.0 & 6.4 & 34 & 23.7 & 4.0 & 18 \\
\hline 6 & 16.1 & 4.5 & 18 & 8.9 & 1.3 & 14 \\
\hline 7 & 47.0 & 1.3 & 16 & 16.2 & 0.8 & 15 \\
\hline 8 & 12.9 & 8.5 & 16 & 7.9 & 0.8 & 11 \\
\hline 9 & 15.9 & 11.6 & 11 & 3.2 & 1.7 & 12 \\
\hline
\end{tabular}




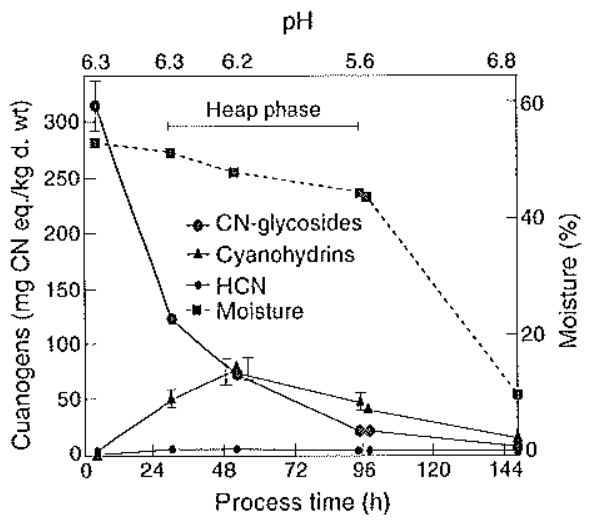

Figure 3. Mean levels of cyanogens ( \pm SD), $\mathrm{pH}$ and moisture in four batches of cassava roots (cv TMS30572) during the process of heap-fermentation at laboratory site.

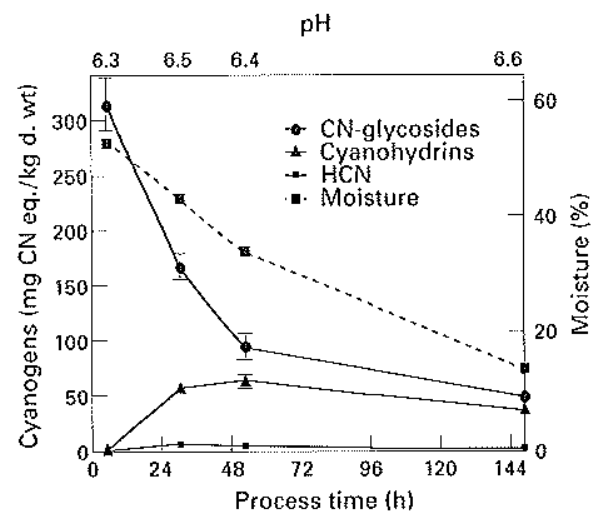

Figure 4. Mean levels of cyanogens $( \pm \mathrm{SD}), \mathrm{pH}$ and moisture in a batch of cassiva roots segments (cv TMS 30572) during the process of sun-drying at laboratory site.

Residual total cyanogen levels in 23 samples of heap-fermented cassava crumbs, collected in 1990 , ranged from 1.4 to $65.8 \mathrm{mg} \mathrm{CN} \mathrm{eq.} \mathrm{kg}^{-1}$ dry weight, with a mean $( \pm S D)$ of $20.3( \pm 16.8)$. Cyanohydrins plus $\mathrm{HCN}$ were not assayed separately.
Residual cyanogenic glucoside levels in the 21 samples of crumbs collected in 1992 varied between 7.1 and $202 \mathrm{mg} \mathrm{CNeq} \cdot \mathrm{kg}^{-1}$ dry weight, with a mean of $56.5( \pm 53.3)$. Residual levels of cyanohydrins plus $\mathrm{HCN}$ varied between 1.2 and $33.4 \mathrm{mg} \mathrm{CN} \mathrm{eq.} \mathrm{kg}^{-1}$ dry weight, with a mean of $9.1( \pm 8.7)$. Moisture levels varied between 13.0 and $19.1 \%$ with a mean of $16.2 \%( \pm 1.4)$. The data of these samples were examined for relationships between levels of glucoside, cyanohydrin plus $\mathrm{HCN}$ and their proportion of the total cyanogen levels on the one hand, and number of storage days, anticipated use and moisture levels, on the other. In the six batches that were meant for sale, cyanogenic glucoside levels (110.0 \pm $65.5 \mathrm{mg} \mathrm{CN} \mathrm{eq.} \mathrm{kg}^{-1}$ dry weight) were significantly $(P=0.0007)$ higher than in the 15 batches meant for own consumption (35.2 \pm 28.4). The relationship was still significant $(P=$ 0.006 ) after correction for the other variables. There was a significant correlation between the anticipaled use of the flours and the cyanohydrins plus $\mathrm{HCN}$ : total cyanide ratio $(P=0.02$, after $\log$ transformation), but this correlation was lost after correction for the effect of the other variables. No other correlations were found.

Two batches of fresh roots of the same variety, harvested in the same village at the time of flour sample collection in 1992, had total cyanogen levels of 580 and $582 \mathrm{mg} \mathrm{CN} \mathrm{eq.} \mathrm{kg}^{-1}$ dry weight. The cassava roots obtained in 1992 were thinner and derived from younger plants than usual, due to drought and depletion of crops in 1991. In 1992, a severe infestation with cassava mosaic disease was observed.

\section{Proteins}

Levels of crude protein and the chemical score of individual essential amino acids in the six fermented and two non-fermented reference

Table 2. Mean levels (SD in brackets) of crude protein and chemical score of individual essentiat amino acids in fermented $(n=6)$ and non-fermented $(n=2)$ flours

\begin{tabular}{|c|c|c|c|c|c|c|c|c|}
\hline \multirow[b]{2}{*}{ Sample' } & \multicolumn{2}{|c|}{ Cntde Protein } & \multicolumn{6}{|c|}{ Chemical seore } \\
\hline & $(g / 100 g d n)$ & Cys + met & $T h r$ & $|a|$ & $H^{\prime}$ & Leu & $T y r+P h t^{\prime}$ & Lys \\
\hline Fermented & $4.5(0.6)$ & $17.5(2.5)$ & $32.0(3.6)$ & $30.3(3.4)$ & $30.7(3.9)$ & $26.2(3.2)$ & $26.0(2.5)$ & $31.0(4.7)$ \\
\hline Non-fermented & $4.7(0.7)$ & $15.5(2.1)$ & $28.0(4.2)$ & $29.1(3.9)$ & $24.5(3.5)$ & $21.0(2.8)$ & $25.5(9.2)$ & $29.0(1.4)$ \\
\hline
\end{tabular}


Table 3. Nicroflora of cassava flour prepared by domestic heap-fermentation

\begin{tabular}{|c|c|c|}
\hline & \multicolumn{2}{|c|}{${ }^{\prime \prime} \log N / g$ (6 sampless) } \\
\hline & Mean & $S D$ \\
\hline Total aerobic mesophiles & 8.45 & 0.23 \\
\hline Lactobacillus spp. & 7.50 & 0.28 \\
\hline Micrococcacene & 7.30 & 0.20 \\
\hline Pseudomonas spp. & 6.60 & (1 sample only') \\
\hline Enterobateriatéte & 6.53 & 0.50 \\
\hline Bacterial endospores & 6.30 & 0.59 \\
\hline Colifonm bacteria & 6.28 & 0.75 \\
\hline Escherichin coli & 4.00 & (1 sample only) \\
\hline Bucillus cereus & $<2.7$ & \\
\hline Clostridium perfingens & $<1.7$ & \\
\hline Staphylococcus amreus & $<1.7$ & \\
\hline Salmonella & Absent in $25 \mathrm{~g}$ & (1 sample only) \\
\hline Yeasts & 6.62 & 0.44 \\
\hline Filamentous fungi & 5.00 & 0.61 \\
\hline
\end{tabular}

Table 4. Filamentous fungi occurring in cassavat flour processed by domestic heap-fermentation

No. of samples. in which detected $(n=6)$

\begin{tabular}{|c|c|c|}
\hline Ilus fumigatus & 3 & niger \\
\hline$A s p e$ & 4 & illus parasiticus \\
\hline in sporotrichioides & 1 & chum candidum \\
\hline es & 2 & $M$ \\
\hline ia & $6^{i 5}$ & $\mathrm{Nel}$ \\
\hline Peni & 1 & Penicillium waksmanii \\
\hline Rhizop & $5^{:}$ & Rhizopus stolonifer \\
\hline
\end{tabular}

"Numerous in each positive sample.

flours are presented in Table 2. The levels in fermented and non-fermented samples were not statistically different, although the chemical scores were on average slightly higher in the fermented samples.
Microflora, mutagenicity and aflatoxins

Tables 3 and 4 specify the microflora in the six flours obtained from the monitored cassava batches at rural households. On the fermenting cassava, green-blue spots, probably indicating conidia of Aspergillus or Penicillium spp. were observed only sporadically. From samples taken during the process, microscopic inspection showed that initially several fungi were present which were not recovered in the resulting flour. During the incubation in heaps, the roots started softening from the outside towards the inside, coinciding with the profuse mould growth, suggesting cellulolytic and pectolytic enzyme activity by the microflora (Okolie \& Ugochukwu, 1988).

The Ames test for mutagenicity and cytotoxicity was negative for all 25 tested flours. A very slight mutagenicity was observed only in the sample of dried scraped-off moulds. Atlatoxins were absent in all 10 screened samples.

\section{Consistency}

Table 5 shows that the viscosity values of the gelatinising flour suspensions rose by increasing the temperature to $95^{\circ} \mathrm{C}$. Maintaining the temperature at $95^{\circ} \mathrm{C}$ resulted in a reduction, followed by a set-back at cooling down. Viscosity in the fermented flours was significantly lower $(P=0.01)$ than in the non-fermented flours at reaching $95^{\circ} \mathrm{C}$, and seemed somewhat higher $(P=0.1$, one-sided) after reaching a temperature at which consumption takes place.

\section{Discussion}

This formerly undocumented heap-fermentation method was capable of reducing cassava cyanogen levels considerably. Starting from the same batch of roots, it resulted in much lower cyanogenic glucoside and cyanohydrin levels

Table 5. Viscosity of gels prepared from femented $(n=5)$ and non-femented $(n=2)$ flours

\begin{tabular}{|c|c|c|c|c|c|c|}
\hline \multirow[b]{3}{*}{ Samples } & \multicolumn{6}{|c|}{ Viscosity (Brabender units) } \\
\hline & \multicolumn{2}{|c|}{ At reaching $95^{\circ} \mathrm{C}$} & \multicolumn{2}{|c|}{ Lowest at $95^{\circ} \mathrm{C}$} & \multicolumn{2}{|c|}{ After cooling to $50^{\circ} \mathrm{C}$} \\
\hline & Mean & $S D$ & Mean & $S D$ & Mean & $S D$ \\
\hline Fermented & 274 & 57 & 185 & 30 & 391 & 114 \\
\hline Non-fermented & 450 & 7 & 163 & 18 & 250 & 14 \\
\hline
\end{tabular}


than sun-drying alone in the same time span. The high cyanohydrin level and the slightly higher moisture level in the flour from the sundried batch indicate insufficient drying. Although the difference in glucoside levels may be explained partly by the splitting of the roots to be sun-dried, the stage of incubation in heaps seems to have had an additional effect on the cyanogen reduction.

The mean level of total cyanogens in the first 23 crumb samples, collected in 1990, was similar to the one from the six flours resulting from the domestic processing monitored by us in the same month and village, and very low compared to levels $\left(133 \pm 71 \mathrm{mg} \mathrm{CN} \mathrm{eq.} \mathrm{kg}^{-1}\right.$ dry weight) found in sun-dried tlours collected in a normal year at households in Masasi, Tanzania (Mlingi et al., 1992). The levels in the products collected in 1992 were higher than the ones from 1990. The levels of cyanohydrins plus $\mathrm{HCN}$ in five out of 21 samples exceeding $10 \mathrm{mg} \mathrm{CN} \mathrm{eq.} \mathrm{kg}^{-1}$ dry weight were higher than the FAO/WHO (1991) recommended upper limit $\left(10 \mathrm{mg} \mathrm{kg}^{-1}\right)$ for hydrocyanic acid content in cassava flour. The total cyanogen levels in all 21 samples were higher than this limit. However, the relation of the linamarin levels to this recommended limit for hydrocyanic acid, which hardly exists in cassava products, is unclear. If this limit is meant to include linamarin levels, it seems to contain ample safety margins (Rosling et al., 1993).

High residual levels of cyanogens may be caused by a high initial level or an inadequate execution of the process, due to poor judgement, negligence or time constraints on the side of the processor, or on purpose for making 'stronger' spirits. Cyanogen levels might have been higher in fresh roots in 1992 due to immaturity. Cyanogen levels in fresh roots were within the same range both years, but the number (two samples) from September 1992 was too small to draw conclusions from. Apparently, although useful in principle, heapfermentation as applied in the studied village does not always lead to sufficient reduction of cyanogens. The 1992 flour samples meant for sale showed significantly higher cyanogen levels than those for home consumption, possibly caused by a shorter fermentation stage. This does not necessarily imply that flour buyers will be more exposed to cyanogens than producers. Marketed fermented flour is often used for brewing, and this purpose was explicitly mentioned for four of the six products to be sold.

\section{Mechanisms involved in the cyanogen reduction}

Levels of cyanogenic glucosides showed an exponential decline during the processes. Cyanohydrin levels rose, due to the breakdown of the glucosides. The conversion rate of glucosides to cyanohydrins was overtaken by that of cyanohydrins to $\mathrm{HCN}$ after 1 or 2 days of incubation. $\mathrm{HCN}$ disappeared nearly simultaneously and was partly lost during extraction and extract storage. The reduction of cyanogen levels during the short cooking step when preparing ugali was negligible.

The first drying step reduced growth conditions for bacteria and enhanced those for fungi. The heap condition, by maintaining adequate moisture levels, extended the time for degradation of cellular structures and linamarin by endogenous enzymes for several days. This process was presumably enhanced by microbial cell wall degrading enzymes, as the roots, contrary to the non-heaped drying controls, started softening from the outside towards the inside, coinciding with the profuse mould growth. Cassava root softening has been shown to be caused by enzymatic cell wall degradation (Okolie \& Oguchukwu, 1988). The barrier of compartmental separation of the linamarin and linamarase was thus further reduced. As several microorganisms can display $\beta$-glucosidase activity (Padmaja \& Balagopal, 1985), their direct involvement in linamarin breakdown is also possible. Laboratory experiments that compared the cyanogen reduction of incubated disinfected cassava with inoculated cassava showed a positive effect from microbial activity (Essers et al., 1994). The $\mathrm{pH}$ of the fermenting cassava, generally between 5.5 and 6.3 , was at the optimum for linamarase activity (Nok \& Ikediobi, 1990). Each of these factors may have effected a continued breakdown of the cyanogenic glucosides and production of cyanohydrins during the heap phase. The higher $\mathrm{pH}$ level towards the end of the process, possibly caused by fungal enzymes like proteases, deaminases and decarboxilases, enhanced the breakdown of cyanohydrins into the volatile hydrocyanic acid. The $\mathrm{pH}$ fluctuations during this process thus facilitated the reduction of 
cyanogen levels. This is quite different from the low $\mathrm{pH}$ generally found with anaerobic fementations as in gari (Vasconcelos $e t a l$., 1990) and soaked cassava (O'Brien et al., 1992).

After crushing of the fermented roots, the larger crumbs showed significantly higher glucosidic and non-glucosidic cyanogen levels than small crumbs from the same batch. This effect was still present after drying. A more thorough crushing of the non-fermented inner parts of the roots would result in faster drying and therefore a shorter period of linamarase activity, which might consequently lead to higher residual glucoside levels. We therefore attribute more value to completion of the fermentation stage than to more intensive crushing for linamarin degradation. Better crushing thereafter may accelerate the drying and thus enhance cyanohydrin removal.

\section{Microflora and mycotoxins}

During on-site macroscopic observation of the moulded heaps, the abundant mycelium and black and orange sporulation of Rhizopus and Neurospora spp. and the white powderedsugar like spots of Geotrichum were remarkable. This corresponds with the finding that these fungi were isolated from all of the flours. Except Newrospora sitophila and Geotrichum candidum, all fungi isolated by us are reported to be able to produce mycotoxins under pure culture laboratory conditions (Northolt, 1988; Frisvad, 1988). This does not imply that they would produce mycotoxins on cassava in the presence of competing fastgrowing microflora. For instance, it was found that Nemospora and Rhizopus spp. are able to suppress the formation of aflatoxins by Aspergillus parasiticus in groundnut (Nout, 1989).

The high number of Escherichia coli found in one of the flour samples is indicative of an unhygienic process. The sporadically found sporeformers Clostridium perfringens and Bacillus cereus might produce toxins after cooking if the ugali would be kept for a long time before consumption.

The absence of atlatoxins, mutagenicity and cytotoxicity in the screened flours does not guarantee that toxic substances were absent. However, it suggests that mycotoxins were not formed in quantities that are detrimental to public health. The occurrence of some strspect fungi as well as a slight mutagenicity in the scraped-off moulds indicate that some mutagenicity might develop during this process. Consequently, it may be useful to maintain the practice of removing the mycelia.

\section{Protein quantity and quality}

All flours showed a high crude protein level and low chemical scores, compared to findings by other authors (Leung, 1968; Ekpenyong, 1984; Gomez \& Noma, 1986; Ezeala, 1984). The protein content and quality, as expressed by chemical score, varied widely and were of the same order after heap-fermentationas after only sun-drying. As most of the moulds were scraped off, most of the formed mycelial protein was lost. The number of samples was too small to confirm or deny an effect on protein quality in general.

\section{Consistency}

The lower viscosity of gels from flours from fermented than from non-fermented roots at $95^{\circ} \mathrm{C}$ correspond with the findings of Moorthy et al. (1993), and the villagers' observation that fermentation facilitates kneading of the ugali, which is considered a heavy task. Ugali from cassava flour is more rubbery than from cereal flours, which is not appreciated. Reducing this rubberiness was one of the objectives and claimed effects of the fermentation. Measuring viscosity is apparently not appropriate to verify the claimed improvements in this rhcological characteristic.

\section{Conclusions}

The heap-fermentation method reduced the cyanogen levels of cassava roots more effectively than sun-drying alone, but it did not always lead to levels below the FAO/WHO suggested limit. The abundant and complex associated microflora played a role in the reduction of cyanogen levels and did not result in detectable mycotoxin contamination of the products. We conclude that the process of heapfermentation is useful in the reduction of cassava's potential toxicity, but there is room for optimisation. Improvements should be sought in ensuring more effective cyanogen removal, a more hygienic product with less 
suspected fungi, and in shortening the time necessary for the process. These objectives might be met by optimising processing conditions including the use of appropriate starter cultures.

Acknowledgements - We thank the late Vincent MakDude and other farmers for their helpful and patient co-operation. We are grateful to Margaret Bosveld, Benjamin Sentongo and Joseph Batamaze for chemical analyses, to Yona Baguma for field assistance, to Ria Westendor) and the Department of Toxicology, Wageningen Agricultural University, for screening for mutagenicity and aflatoxins, to Claudia Witjes and Marion Bennik for microflora isolation and identification, and to the Depariment of Food Science and Techuology of Makerere University and Namulonge Research Station for infrastructural and logistical suppoit. This study was fintmeed by the Netherlands" Minister for Development Co-operation.

\section{References}

Anderson GW (1944): Notes on cassava preparation in noth Kavirondo and Samia. E. Afri Agric. J. 10, $111-112$.

Childs AHB (1961): Cassava. Ball. Dep. Agric. Tangamyika $15,1-5$.

Cooke RD (1978): An enzymatic assay for the total cyanide content of cassava (Manihot esculenta Crantz). J. Sci Fool Agrit. 29, 345-352.

De Bruijn GH (1971): Etude du caractère cyatnogénétiųte du manioe (Nanihot Esculenta Crantr). Meded. Landbutublogesch. Wageningen 71, p. 140. Wageningen, The Netherlands.

Ekpenyong TE (1984): Composition of some tropical uberous foods. Fond Chem. 15, 31-36.

Essers AJA, Alsén P \& Rosling H (1992): Insulficient processing of cassava induced acute intoxications and the paralytic disease konzo in a nral area of Mozambique. Ecol. Food Nutr: 27, 17-27.

Exsers AJA, Bosveld M, Van der Grift RN \& Voragen AG. (1993): Studies on the quantification of specific cyanogens in cassiva products and introduction of a new chromogen. J. Sci. Food Agric. 63, 287-296.

Essers AJA, Witjes CMIW, Schurink EWV \& Nott MJR (1994): Role of fungi in cyanogens removal during solid substrate fermentation of cassava. Biot. Lett. 16, $755-758$.

Ezeala DO (1984): Changes in the nutritional quality of fermented cassavat uber meal. J. Agric. Food Chem. 32, $467-469$.

Food and Agriculture Organization/Vorld Health Organization (FAO/WHO) (1972): Joint FAO/WHO expert committee on energy and protein requirements. Rome: FAO.

Food and Agriculture Organization/Norld Health Organization (FAO/WHO) (1991): Joint FAO/VHO Food Standards Programmc. Codex standards for miscellaneous products, Supplenent 4. Rome: FAO/VHO.

Filtentrorg O, Frisvad JC \& Svendsen JA (1983): Simple screening methods for molds producing intracellutar mycotoxins in pure cultures. Appl. Environ. Hicrobiol. $45,581-585$.

Frisvad JC (1988): Fungal species and their specific production of myeotoxins. In Introluction to Foot-bome Fungi, eds RA Samson \& ES van Reenen-Hoekstra, pp. 239-249. Baarm, The Netherlands: Centraalbureau voor schimmelcultures.

Gómez G, Noma AT (1986): The amino acid composition of cassavia leaves, foliage, root tissues and whole-root chips. Nutr: Rep. Imt. 33, 595-601.

Goode PM (1974): Some local vegetables and fruits of
Uginda. Cited in: Lancaster PA, Ingram IS, Lim MY \& Coursey DG (1982): Traditional cassava based foods: Survey of processing techniques. Econ. Botany 36, $12-45$.

Leung WTW (1968): Food composition table for use in Africa. Nutrition Information Document Series 3. FAO, Rome: Food and Agriculture Organization (FAO).

Maron DM \& Ames BN (1983): Revised methods for the satmonella mutagenicity test. Wutat. Re's. 113. $17 \mid-215$

Melville B (1993): Rapid rumal appraisal: its role in health planning in developing countries. Trop. Doct. April $55-58$.

Mkpong O, Hua-Yan E, Chism $G$ \& Sayre R' (1990): Purfification, characterization and location of linamarase in cassitva. Plant Physiol. 93, 176-181.

Mlingi N, Poulter NH \& Rosling H (1992): An outbrak of acute intoxications from consumption of insufficiently processed cassava in Tanzania. Nutr: Res. 12, 677-687.

Moorthy SN, George M \& Pidmaja G (1993): Functional properties of the starchy llotr extritcted from cassitvit on iementation with a mixed culture inoculum. J. Sti. Food Agric: 61, 443-448.

Nok AJ \& lkediobi CO (1990): Purification and some properties of linamirase from cassava (Manihot esculenta) cortex. J. Food Biochem. 14, 477-489.

Northolt MD (1988): Fingal growth on foodstuffs related to mycotoxin contanination. In Introduction to Food-bonze' Fungi, eds RA Samson \& ES van Reenen-Hoekstri, pp. 239--249. Baarn, The Netherlinds: Centratalbureatu voor schimmelculures.

Nout MJR (1989): Effect of Rhizenus and Netwospora spp. on growth of Aspergillus flatus and $A$. paraciticus and accumulation of aflatoxin $\mathrm{B}_{1}$ on ground nut. Wycol. Rex. $93,518-523$

O'Brien GM, Taylor AJ, Poulter NH (1991): Improved enzymic assiy for cyanogens in fresh and processed cassava. J. Sit. Food Agric. 56, 277-289.

O'Brien GM, Mbome L. Taylor AJ \& Poulter NH (1992): Variations in eyanogen content of cassava during village processing in Cameroon. Food Chem. 44, 131-136.

Okolie NP \& Ugochukwa EN (1988): Changes in activities of cell wall degrading enzymes during lermentation of cassava (Manihot esculenta Crantz) with Citrobacter fremulii. J. Sci. Food Agric: 44, 51-61.

Padmaja ( \& Balagopal C (1985): Cyanide degradation by Rhizopus oryzat. Cam. J. Microbiol. 31, 663-669.

Romanoff S \& Lynam J (1992): Cassatva and African food security: some ethnographic examples. Ecol. Food Nutr: $27,29-41$. 
Rosling $\mathrm{H}$, Mlingi N, Tylleskär T \& Banca M (1993): Cansal mechanisms behind human diseases induced by cyanide exposure from cassava. In Proceedings from the First Meeting of the Cassava Biotechology Nen'ork, Cartagen, Colombia, 25-28'August 1992, eds WN Roca \& AN Thro. Cali, Colombia : Centro Internacional de Agricutura Tropical (CIAT).

Samson RA \& Van Reenen-Hoekstra ES (eds) (1988): Introdution to Food-bone Fumgi. Baam, The Netherlands: Centraalburean wor schimmelsultures.

Snedecor GW \& Cochran WG (1980); Statistical Methods, 7th tedn, p. 507. USA: Iowa State University Press.
Soarez LMV \& Rodriguez-Amaya DB (1989): Survey' of aflatoxins, ochratoxin A, zearateone, and sterigmatocystin in some Brazilian foods by using milti-toxin thinlayer chromatographic method. J. AOAC 72, 22-25.

Stein WH \& Moore S (1963): Chromatographic determination of amino acids by use of automatic recording equipment. In Methods in Enzymology, eds SP Colowick \& NO Kaplan, pp. 819-831. New York: Academic Press.

Vasconcelos AT, Twiddy DR, Westby A \& Reilly PJA (1990): Detoxification of cassava during gari preparation. Itt. J. Food Sci. Ted $/$ mol. 25, 298-203. 